\title{
Author's reply to Mandarino et al.: The prophylactic use of endoscopic vacuum therapy for anastomotic dehiscence after rectal anterior resection-isit feasible for redo surgery?
}

\author{
N. C. Lehwald-Tywuschik ${ }^{1} \cdot$ A. Alexander ${ }^{1} \cdot$ N. Alkhanji ${ }^{1}$ - G. E. W. Flügen ${ }^{1} \cdot$ S. Fung ${ }^{1} \cdot$ A. Rehders $^{1} \cdot$ W. T. Knoefel ${ }^{1}$
}

Received: 6 February 2022 / Accepted: 6 February 2022 / Published online: 26 February 2022

(c) The Author(s) 2022

Dr Madarino et al. report on a novel application of prophylactic EVT treatment after redo surgery in case of anastomotic dehiscence [1]. The approach of combining redo surgery and enforcing the operative result though EVT is convincing and the result in this case is encouraging. Sufficient mobilization of the anastomotic bowel walls and preserving vascularisation of these margins will be crucial. We congratulate Dr Mandarino et al. on this innovative approach.

Funding Open Access funding enabled and organized by Projekt DEAL.

Open Access This article is licensed under a Creative Commons Attribution 4.0 International License, which permits use, sharing, adaptation, distribution and reproduction in any medium or format, as long as you give appropriate credit to the original author(s) and the source, provide a link to the Creative Commons licence, and indicate if changes were made. The images or other third party material in this article are included in the article's Creative Commons licence, unless indicated otherwise in a credit line to the material. If material is not included in the article's Creative Commons licence and your intended use is not permitted by statutory regulation or exceeds the permitted use, you will need to obtain permission directly from the copyright holder. To view a copy of this licence, visit http://creativecommons.org/licenses/by/4.0/.

\section{Reference}

1. Mandarino FV, Barchi A, Biamonte P et al (2022) The prophylactic use of endoscopic vacuum therapy for anastomotic dehiscence after rectal anterior resection: is it feasible for redo surgery? Tech Coloproctol. https://doi.org/10.1007/s10151-021-02566-w

Publisher's Note Springer Nature remains neutral with regard to jurisdictional claims in published maps and institutional affiliations.
W. T. Knoefel

knoefel@hhu.de

1 Departments of Surgery, University Hospital Duesseldorf and Heinrich-Heine-University Duesseldorf, Moorenstrasse 5, 40225 Düsseldorf, Germany 